\title{
Pentingnya Kesehatan Gigi dan Mulut pada Anak Usia Sekolah di RT 10 Kelurahan Murni Kota Jambi
}

\author{
Vevi Suryenti Putri ${ }^{1}$, Martha Suri ${ }^{2}$ \\ 1,2 Program Studi S1 Keperawatan, Sekolah Tinggi Ilmu Kesehatan Baiturrahim Jambi \\ Email : vevisuryentiputri@gmail.com
}

Submitted : 16/03/2021

Accepted: 08/01/2022

Published: 28/01/2022

\begin{abstract}
Brushing your teeth is a basic technique for controlling and preventing bacterial infections in the mouth. Brushing teeth is the process of removing dirt and bad breath mechanically from the mouth by using toothpaste and toothpaste and rinsing with clean water (Irma \& Intan, 2013). Based on the assessment conducted through interviews, observations and distribution of questionnaires obtained data in RT 10 Kelurahan Murni with a total of 47 households and 172 population, namely school age children 6-12 years have the habit of brushing teeth 1 and 2 times a day 50.0\% and the condition of the teeth perforated and black 61.1\%. Counseling activities carried out for 45 minutes with the stages of directing participants to the place to be counseling, opening by the moderator, delivering counseling material delivered by the presenter, demonstrating how to brush teeth correctly, distributing leaflets to participants and documenting activities. The results of the counseling of the participants were able to explain again the meaning of brushing their teeth $78.9 \%$, the purpose of brushing their teeth $78.3 \%$, the benefits of brushing their teeth $81.6 \%$, the danger of not brushing their teeth $81.6 \%$, when brushing their teeth $81.6 \%$ and their steps step brushing teeth $84.2 \%$.
\end{abstract}

Keywords : brushing your teeth, school chlidreen

\begin{abstract}
Abstrak
Menggosok gigi adalah teknik dasar untuk melakukan pengontrolan dan pencegahan infeksi bakteri di mulut. Menggosok gigi adalah proses pembuangan kotoran dan bau mulut secara mekanis dari mulut dengan memakai pasta gigi dan odol dan dikumur dengan air bersih (Irma \& Intan,2013). Berdasarkan pengkajian yang dilakukan melalui wawancara, observasi dan penyebaran kuesioner didapatkan data di RT 10 Kelurahan Murni dengan jumlah 47 KK dan 172 jumlah penduduk yaitu anak usia sekolah 6-12 tahun memiliki kebiasaan menggosok gigi 1 dan 2 kali sehari 50,0\% dan kondisi gigi berlubang dan hitam $61,1 \%$. Kegiatan penyuluhan dilaksanakan selama 45 menit dengan tahapan mengarahkan peserta ke tempat yang akan dilakukan penyuluhan, melakukan pembukaan yang disampaikan moderator, menyampaikan materi penyuluhan yang disampaikan oleh penyaji, mendemonstrasikan cara menggosok gigi yang benar, membagikan leaflet pada peserta dan mendokumenatsikan kegiatan. Hasil dari penyuluhan peserta mampu menjelaskan kembali pengertian manggosok gigi 78,9\%, tujuan menggosok gigi 78,3\%, manfaat menggosok gigi $81,6 \%$, bahaya tidak menggosok gigi $81,6 \%$, waktu menggosok gigi $81,6 \%$ dan langkahlangkah menggosok gigi $84,2 \%$.
\end{abstract}

Kata kunci : anak sekolah, gosok gigi

\section{PENDAHULUAN}

Kesehatan gigi dan mulut merupakan bagian dari kesehatan jasmani yang tidak dapat dipisahkan satu dan lainnya karena akan mempengaruhi tubuh secara keseluruhan (Lossu dkk.,2015). Dengan memiliki gigi dan mulut yang sehat, beberapa aktifitas seperti berbicara, makan, dan bersosialisasi tidak akan terganggu karena terhindar dari rasa sakit, tidak nyaman, dan malu. Kenyataannya sampai saat ini tingkat kesehatan gigi dan mulut masyarakat Indonesia masih rendah. Di dunia 60-90\% anak sekolah mengalami karies (WHO,2011). Hal ini terlihat dari peningkatan angka penduduk Indonesia 
yang memiliki masalah gigi dan mulut pada tahun 2007 sebanyak 23\% sedangkan pada tahun 2013 sebanyak 26\% Kemenkes RI, 2007 \&2013 ).

Masalah - masalah kesehatan yang sering terjadi pada anak usia sekolah dasar adalah penyakit yang berhubungan dengan kebersihan diri anak dan lingkungan seperti gosok gigi yang baik dan benar, kebiasaan cuci tangan pakai sabun, dan kebersihan diri. Penyakit yang sering muncul adalah diare, kecacingan, sakit gigi dan lain sebagainya (Saputra, 2013 dalam (Fatmawati, 2018). Salah satu prevalensi penyakit gigi dan mulut yang tinggi adalah karies gigi. Studi epidemiologi mengenai karies menunjukkan bahwa prevalensi karies meningkat pada negara berkembang (Aubrey dan Marcelo, 2006). Berdasarkan Riset kesehatan dasar tahun 2018 mengatakan bahwa Di Indonesia anak Indonesia usia 5-9 tahun mengalami masalah gigi dan mulut dengan persentase $57,6 \%$. provinsi sulawesi tengah urutan paling tertingi yang memiliki masalah kesehatan gigi dan mulut dengan persentase 73,5\% dan Provinsi Kepulauan Riau urut terendah dengan masalah kesehatan gigi dan mulut pada anak sebesar 45,0\%. Sedang di provinsi Jambi masalah kesehatan gigi dan mulut sebesar $43,5 \%$.

Karies gigi merupakan permasalahan gigi yang sering timbul tidak hanya pada orang dewasa tetapi juga dialami oleh anak-anak. Oral hygiene yang buruk dapat menjadi salah satu faktor resiko terjadinya karies. Di dunia 60-90\% anak sekolah mengalami karies (WHO,2011).

Salah satu faktor penyebab timbulnya masalah kesehatan gigi dan mulut pada anak-anak adalah faktor perilaku, hal ini ditunjukkan dengan anakanak yang mengabaikan kesehatan gigi dan mulut. Hal tersebut terjadi karena kurangnya pengetahuan mengenai pentingnya menjaga kesehatan gigi dan mulut. Perilaku memegang peran penting dalam mempengaruhi kesehatan gigi dan mulut. Oleh karena itu, perilaku dapat mempengaruhi baik buruknya kebersihan gigi dan mulut, termasuk mempengaruhi angka kejadian karies ( Widayati,2014).

Karies gigi adalah pembentukan lubang pada permukaan gigi yang diakibatkan oleh adanya plak yang melekat pada permukaan gigi atau gusi. Karies gigi yang apa bila tidak dirawat maupun dicegah dengan baik dan benar, akhirnya dapat menyebabkan kerusakan pada jaringan penyanggah gigi. Kurangnya perawat gigi pada anak bertambah buruk karena anak banyak mengkonsumsi makanan dan minuman yang menyebabkan: Gigi berlubang (Susanto, 2007). Awal perjalanan penyakit karies dimulai dengan bercak berwarna cokelat atau putih. Semua gigi yang memiliki bercak kecokelatan atau keputihan di permukaan emailnya dapat didiagnosis terkena karies. Meskipun belum nampak secara fisik lubang besar pada gigi, gigi telah positif terkena karies (Erwana, 2013)

Perilaku hidup bersih dan sehat yang sederhana seperti menggosok gigi merupakan salah satu meningkatkan kesadaran masyarakat tentang pemeliharaan kesehatan pribadi dan pentingnya berprilaku hidup bersih dan sehat (Retno, 2013). Kebiasaan menggosok gigi dapat mencegah terjadi wajib selama menggosok gigi. Namun data yang di masyrakat menunjukan bahwa perilaku yang benar di masyarakat masih rendah (Arisman, 2019).

Cara menggosok gigi yang benar yaitu pipih pasta gigi yang tepat sesuai gigi kamu , ratakan pasta gigi masukan sikat gigi yang telat di beri pasta gigi ke dalam mulut, sikat membentuk sudut 45 derajat, sikat gigi graham. Gosok secara vertikal. Upaya pemeliharaan kesehatan gigi dengan menggosok gigi sebaiknya di lakukan sedemi mungkin sehingga sampai terjadi pada anak - anak (Septianingsih \& Sulistyowati,2017) 
Upaya yang dapat dilakukan untuk mencegah terjadinya karies tentu sudah jelas, ialah menggosok gigi dengan pasta gigi (sebaiknya segera sesudah makann, disamping tidak mengkonsumsi makanan yang lengket atau bergula, menggosok gigi sangat perlu dilakukan karna apabila karies yang terjadi pada gigi tsangat rentan pada anak memang tidak berbahaya, namun kejadian ini biasanya berlanjut sampai anak memasuki usia remaja bahkan sampai dewasa gigi yang berkurang akan menyerang gigi permanen sebelum gigi tersebut berhasil menembus gusi (Arisma, 2019).

Menggosok gigi dengan pasta gigi dan odol yang dipraktekkan dengan tepat dan benar merupakan cara termudah dan efektif untuk mencegah terjangkitnya penyakit karies gigi, gigi berlubang, sakit gigi.. gi dan odol lebih efektif menghilangkan kotoran dan bau mulut, dan secara bermakna dapat mengurangi jumlah mikroorganisme penyebab penyakit seperti virus, bakteri, dan parasite lainnya pada rongga mulut (Arisman,2019).

Dampak masalah kesehatan yang timbul akibat tidak menggosok gigi yaitu gigi berlubang, akan terjadi ompong, karies gigi dan menyebabkan sakit dan bahkan terjadi bengkak pada pipi (Kemenkes, 2016).

Menurut penelitian yang dilakukan Rara Warih Gayatri (2017) "Phubungan tingkat pengetahuan dengan perilaku pemeliharaan kesehatan gigi anak SDN Kauman 2 Malang" menunjukan bahwa ada pengaruh penyuluhan menggosok gigi terhadap pengetahuan siswa SD tentang cuci tangan pakai sabun SDN Kauman 2 Malang.

Menurut penelitian yang dilakukan oleh Sri Handayani (2018) dengan judul penelitian " Pengaruh Penyuluhan Mengenai Menyikat Gigi Yang Benar Terhadap Peningkatan Pengetahuan Siswa" menunjukan bahwa efektif menggosok gigi menggunakan pasta gigi yang lembut dan berbahan aktif.

Berdasarkan pengkajian yang dilakukan melalui wawancara, observasi, dan penyebaran kuesioner didapatkan data di RT 10 dengan jumlah $47 \mathrm{KK}$ dan 172 jumlah penduduk. Didapatkan hasil dari 18 orang anak usia sekolah di wilayah RT. 10 didapatkan masalah kebiasaan menggosok gigi 1 dan 2 kali yaitu sebanyak 9 orang dengan persentase 50,0 $\%$, kondisi gigi berlubang dan hitam yaitu 11 orang anak dengan persentase $61,1 \%$. Dari hasil wawancara diketahui bahwa anak sekolah kebiasaan tidak menggosok gigi dan tidak menyadari timbulnya penyakit akibat dari kebiasan tidak menggosok gigi seperti karies gigi, gigi berlubang, bengkak dan ompong, dalam hal ini penyuluhan kesehatan sangat lah penting bagi masyarakat agar lebih memahami tentang penyakit tersebut dan dapat merubah pola hidupnya agar tercapainya hidup sehat.

Berdasarkan permasalahan yang telah didapatkan, untuk meningkatkan kesadaran masyarakat tentang kebiasaan menggosok gigi sehingga masyarakat mau melaksanakan menggosok gigi perlu diadakan penyuluhan kesehatan tentang kebersihan gigi dan mulut.

\section{TARGET DAN LUARAN}

1. Target

Dari permasalahan mitra yang dipaparkan terdapat salah satu masalah yang ditemukan di RT 10 Kelurahan Murni yaitu anak usia sekolah memiliki kebiasaan menggosok gigi 1 dan 2 kali sehari dan kondidi gigi yang berlubang dan hitam.

Rencana tindak lanjut dari permasalahan kebersihan gigi dan mulut akan berkoordinasi dengan piham puskesmas Putri Ayu dalam Program usaha kesehatan gigi sekolah (UKKGS) untuk mengadakan penyuluhan tentang karies gigi disekolah-sekolah yang dilaksanakan setiap 6 bulan sekali. 


\section{Luaran}

Dari penyuluhan yang kami sampaikan diharapkan anak usia sekolah di RT 10 kelurahan Murni dapat mengetahui dan memahami :

a. Anak usia sekolah dapat menjelaskan kembali pengertian menggosok gigi

b. Anak sekolah dapat menyebutkan tujuan menggosok gigi

c. Anak usia sekolah dapat menyebutkan manfaat dari menggosok gigi

d. Anak usia sekolah dapat menyebutkan dampak dati tidak melaukan menggosok gigi

e. Anak usia sekolah dapat menyebutkan waktu untuk menggosok gigi

f. Anak usia sekolah dapat mempraktik cara menggosok gigi yang benar

g. Anak usia sekolah mampu mendemonstrasikan tentang langkah menggosok gigi yang benar

\section{METODE PELAKSANAAN}

Perencanaan kegiatan dimulai dengan survei lapangan oleh tim pengabdian. Survei lapangan dilakukan oleh tim pengabdian pada bulan Maret 2020. Permasalahan yang ditemukan adalah banyaknya kasus karies gigi yang terjadi pada anak usia sekolah khususnya siswa/siwi di RT 10 Kelurahan Murni. Solusi kepada pihak warga RT 10 untuk menyelesaikan masalah tersebut. Solusi yang ditawarkan adalah memberikan pendidikan kesehatan yang dilaksanakan pada bulan Juni 2020.

Pelaksanaan Kegiatan

Tahapan pelaksanaan kegiatan pengabdian kepada masyarakat ini adalah sebagai berikut:

1. Persiapan

a) Survey awal permasalahan pada lahan yang akan dilakukan pengebdian masyarakat.

b) Menyusun proposal kegiatan pengabdian kepada masyarakat. Pengadaan Poster/media c) Menyiapkan materi/bahan presentasi tentang konsep gosok gigi

2. Pelaksanaan Kegiatan

a) Perkenalan, diskusi tim serta menjelaskan kegiatan yang akan dilakukan

b) Edukasi pada anak usia sekolah tentang pentingnya kesehatan gigi dan mulut di RT 10 Kelurahan Murni melalui media infocus, poster dan leafleat.

c) Demonstrasi tentang penggunaan gosok gigi yang benar

d) Tanya jawab/ diskusi

e) Penutupan

3. Monitoring dan Evaluasi

Monitoring dan evaluasi (Monev) dilakukan secara langsung kepada sasaran. Cakupan Monev dalam kegiatan ini meliputi monev perencanaan dan pelaksanaan dan evaluasi hasil.

\section{HASIL DAN PEMBAHASAN}

Dari penyuluhan yang disampaikan kepada 38 peserta dapat mengetahui tentang :

Sebelum disampaikan penyuluhan, kelompok melakukan pretest (sebelum) diberikan edukasi untuk menggali pengetahuan anak usia sekolah didapatkan hasil 55,3\% anak menjawab benar tentang pengertian menggosok gigi dan setelah diberikan penyuluhan terhadap 38 anak didapatkan hasil posttest (sesudah) diberikan edukasi diperoleh hasil 78,9\% anak menjawab benar tentang pengertian menggosok gigi. Dari hasil tersebut dapat ditarik kesimpulan bahwa anak-anak yang telah diberi penyuluhan bisa mengerti dan memahami pengertian dari menggosok gigi sebagai berikut :

Menggosok gigi adalah teknik dasar untuk melakukan pengontrolan dan pencegahan infeksi bakteri di mulut. Menggosok gigi adalah proses pembuangan kotoran dan bau mulut secara mekanis dari mulut dengan memakai pasta gigi dan odol 
dan dikumur dengan air bersih (Irma \& Intan,2013).

Pretest yang kedua yang dilakukan kelompok mengenai tujuan menggosok gigi didapatkan hasil $60,5 \%$ anak menjawab benar tentang tujuan menggosok gigi. Setelah dilakukan penyuluhan terhadap 38 anak didapatkan hasil posttest (sesudah) diberikan edukasi diperoleh hasil 78,3\% anak menjawab benar tentang tujuan menggosok gigi. Hal ini menunjukan terjadi peningkatan pemahaman anak usia sekolah dalam memahami tujuan menggosok gigi sebagai berikut :

a. Mencegah karies gigi dan mencegah gigi berlubang

b. Mencegah atau mengurangi peristiwa infeksi

c. Memelihara tekstur dan integritas gig tangan dengan tepat (Irma \& Intan,2013).

Pretest yang ketiga yang dilakukan kelompok mengenai manfaat menggosok gigi didapatkan hasil 57,9\% anak menjawab benar tentang manfaat menggosok gigi. Setelah dilakukan penyuluhan terhadap 38 anak didapatkan hasil posttest (sesudah) diberikan edukasi diperoleh hasil 81,6\% anak menjawab benar tentang manfaat menggosok gigi sebagai berikut :

a. Menjaga gigi lebih bersih dan sehat

b. Mencegah penyakit radang gusi

c. Memperbaiki masalah bau mulut

d. Membersihkan sisa makanan

e. Menghilangkan bau mulut

f. Menurunkan resiko sakit gigi

g. Mencegahan gigi berlubang

h. Menjaga kesehatan mulut yang optimal

i. Mencegah kerontokan gigi

j. Menghilangkan noda (Irma \& Intan,2013).

Pretest yang keempat yang dilakukan kelompok mengenai waktu untuk menggosok gigi didapatkan hasil 63,2\% anak menjawab benar tentang waktu untuk menggosok gigi. Setelah dilakukan penyuluhan terhadap 38 anak didapatkan hasil posttest (sesudah) diberikan edukasi diperoleh hasil $81,6 \%$ anak menjawab benar tentang waktu untuk menggosok gigi sebagai berikut :

Waktu untuk menyikat gigi di pagi dan sore saat mandi, bisa meningkatkan risiko kerusakan gigi, seperti lubang dan plak, yang terbentuk dari endapan sisa makanan. Itulah kenapa sebaiknya kita menyikat gigi 2 kali sehari setelah sarapan dan malam hari sebelum tidur (Irma \& Intan,2013).

Pretest yang kelima yang dilakukan kelompok mengenai bahaya tidak menggosok gigi didapatkan hasil 55,3\% anak menjawab benar tentang bahaya tidak menggosok gigi. Setelah dilakukan penyuluhan terhadap 38 anak didapatkan hasil posttest (sesudah) diberikan edukasi diperoleh hasil $81,6 \%$ anak menjawab benar tentang bahaya tidak menggosok gigi sebagai berikut:

a. Gigi berlubang

Kuman dan bakteri yang jarang dibersihkan jelas membuat lubang di gigi, bukan Cuma sakit rasanya, mengunyah makanan pun menjadi tidak sempurna jika gigi banyak yang berlubang.Salah satu alasan utama rajin mencuci tangan adalah untuk meminimalkan perpindahan virus dan bakteri melalui tangan kita, jika jarang cuci tangan, perpindahan virus atau bakteri ini akan memicu mudahnya untuk terkena pilek.

b. Gangguan pernafasan

Malas gosok gigi rupanya mempengaruhi paru - paru. Berbagai penyakit yang berhubungan dengan masalah pernafasan pun muncul. Misalnya asma, infeksi, kanker paru paru, dan lainnya.

Gambar 1. Kegiatan edukasi

c. Gusi berdarah

Infeksi pada jaringan dan tulang yang mendukung gigi bisa terjadi jika isi mulut jarang dibersihkan, Gusi pun rentan mengalami pendarahan dan menimbulkan infeksi tersebut. 
d. Bau mulut

Masalah yang cukup menggangu akibat dari malas merawat kesehatan gigi adalah munculnya bau mulut, Bau mulut membuat kepercayaan diri menurun, karena kerap memberi aroma tidak sedap saat sedang berbicara dengan orang lain. Untuk mencegah bau mulut, harus menjaga pola makanan yang sehat, menyikat gigi dua kali sehari, dan melakukan pemeriksaan rutin ke dokter gigi setiap enam bulan sekali (Irma \& Intan,2013).

Pretest yang keenam yang dilakukan kelompok mengenai langkah-langkah menggosok gigi didapatkan hasil 57,9\% anak menjawab benar tentang langkahlangkah menggosok gigi. Setelah dilakukan penyuluhan terhadap 38 anak didapatkan hasil posttest (sesudah) diberikan edukasi diperoleh hasil $84,2 \%$ anak menjawab benar tentang langkah-langkah menggosok gigi.

Rencana tindak lanjut dari permasalahan kebersihan gigi dan mulut akan berkoordinasi dengan piham puskesmas Putri Ayu dalam Program usaha kesehatan gigi sekolah (UKKGS) untuk mengadakan penyuluhan tentang karies gigi disekolah-sekolah yang dilaksanakan setiap 6 bulan sekali.

Berdasarkan data sebelum edukasi 55,3\% kurang pengetahuan tentang menggosok gigi, setelah dilakukan edukasi selama 45 menit terhadap 38peserta didapatkan hasil posttest $78,9 \%$ yang artinya terjadi peningkatan sebelum dan sesudahn dilakukan edukasi $23,6 \%$.

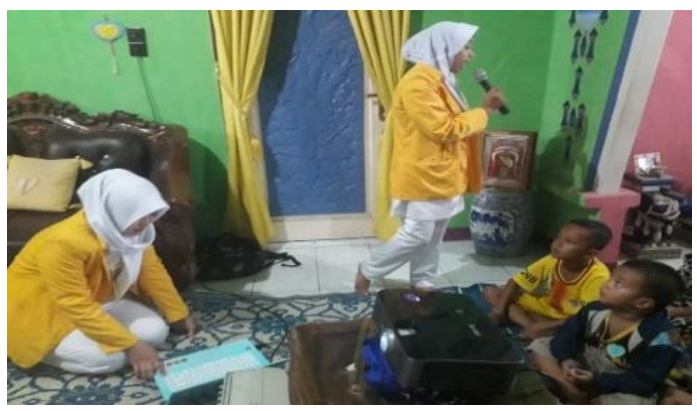

Menurut penelitian yang dilakukan Prasko (2018) dengan judul "Peyuluhan metode audio visual dan demonstrasi terhadap pengetahuan menyikat gigi pada anak sekolah dasar" menunjukan bahwa ada pengaruh penyuluhan menggosok gigi yang benar terhadap pengetahuan siswa sekolah dasar tentang menggosok gigi pada anak sekolah dasar..

Menurut penelitian yang dilakukan oleh Sri Handayani (2017) dengan judul penelitian " Pengaruh penyuluhan mengenai menyikat gigi yang benar terhadap peningkatan pengetahuan siswa" menunjukan bahwa efektif menggosok gigi menggunakan sikat gigi yang lebut dan odol berbahan aktif.

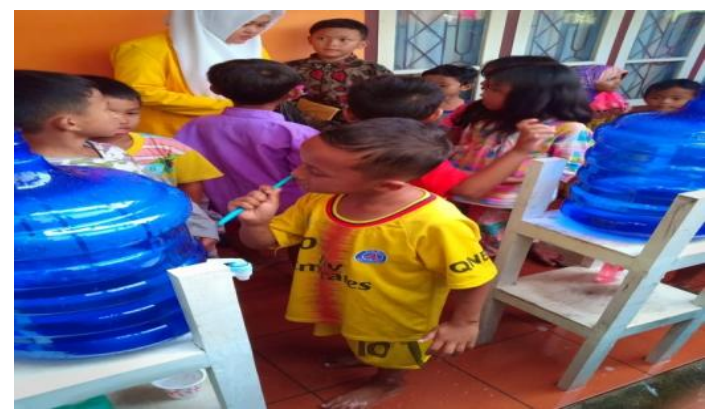

Gambar 2 kegiatan gosok gigi

Setelah dilaksanakan penyuluhan pada anak usia sekolah peserta dapat menyebutkan tentang menggosok gigi :

1. Dapat menjelaskan kembali pengertian menggosok gigi

2. Dapat menyebutkan tujuan menggosok gigi

3. Dapat menyebutkan manfaat menggosok gigi

4. Dapat menyebutkan waktu untuk menggosok gigi

5. Dapat menyebutkan bahaya tidak menggosok gigi

6. Dapat menyebutkan langkah menggosok gigi yang benar

Menggosok gigi adalah teknik dasar untuk melakukan pengontrolan dan pencegahan bakteri pada mulut. Menggosok gigi adalah proses pembuangan kotoran dan bau mulut dengan memakai sikat gigi yang lemut dan 
odol serta dikumur - kumur dengan menggunakan air yang bersih (Irma \& Intan,2013).

Tujuan menggosok gigi yaitu mengurangi mikroorganisme dan bau mulut dan mencegah gigi berlubang dan memelihara tekstur dan integritas gigi dengan tepat (Irma \& Intan,2013).

Manfaat mengosok gigi yaitu mencegah gigi berlubang, jika malam hari sudah menyikat gigi dan pagi harinya setelah makan pagi kita menyikat gigi kembali, maka resiko terjadinya penumpukan plak dalam rongga mulut kita secara otomatis akan berkurang sehingga akan mencegah resiko nterjadinya gigi berlubang (Irma \& Intan,2013).

Adapun waktu untuk menggosok gigi yaitu menyikat gigi di pagi dan sore saat mandi, bisa meningkatkan risiko kerusakan gigi, seperti lubang dan plak, yang terbentuk dari endapan sisa makanan. Itulah kenapa sebaiknya kita menyikat gigi 2 kali sehari setelah sarapan dan malam hari sebelum tidur (Irma \& Intan,2013).

Bahaya tidak menggosok gigi yaitu mengakibatkan gigi mudah berlubang, gangguan pernafasaan, gusi berdarah dan bau mulut (Irma \& Intan, 2013).

Langkah-langkah menggosok gigi yang benar : langkah pertama genggam sikat gigi anda dengan menempatkan sudut kepala sikat agak miring dengan posisi membentuk sudut 45 derajat, jadi tidak menempelkan keseluruhan permukaan bulu sikat di gigi, langkah kedua bisa mulai menyikat dari gigi depanatau gigi graham di salah satu sisi mulut. Sikatlah gigi dengan gerakan melingkar dari atas ke bawah selama 20 detik untuk bagian. Teknik ini berfungsi supaya bulu sikat dapat mengeluarkan plak yang menyelip di batas gusi. Selama penyikat gigi pastikan telah tetap menjaga posisi bulu nsikat sedikit miring membentuk sudut 45 derajat, langkah ketiga sikatlah gigi yang biasa dipakai untuk mengunyah, yaitu bagian gigi yang dekat dengan pipi dan lidah, dengan gerakan maju mundur secara perlahan. Setelah bagian atas dalam tersikat, kemudian sikatlah bagian bawahnya. Pastikan semua permukaan gigi sudah di sikat, sehingga plak atau sisa makanan yang menempel di gigi bisa hilang.

Langkah ke empat Untuk membersihkan permukaan dalam barisan gigi depan, anda harus memegang sikat gigi secara vertikal. Gunakan ujung kepala sikat gigi dan sikat dengan gerakan ke atas dan bawah, dari tepi gusi sampai atas gigi, langkah kelima sama dengan langkah keempat, arahkan sikat gigi agak tegak untuk membersihkan gigi depan bagian bawah, gerakan sikat ke atas dan ke bawah pelan - pelan dan langkah keenam Kadang - kadang, menyikat gigi dengan cara yang itu - itu saja membuat bagian lain yang tidak biasa dilewati bisa terabaikan, itu sebabnya, bila diperlukan bisa mengubah pola menyikat gigi yang biasa.Menggosok gigi bisa menghabiskan waktu sekitar 2-3 menit untuk menyikat seluruh bagian gigi (Irma \& Intan,2013).

\section{KESIMPULAN DAN SARAN}

\section{Kesimpulan}

Kegiatan ini dilaksankan pada bulan Juni di Rumah Ketua RT 10 Kelurahan Murni Kegiatan ini dihadiri oleh 38 orang anak usia sekolah dan 10 orang tua dari anak di RT 10 Kelurahan Murni. Hasil dari kegiatan penyuluhan yang telah disampaikan meskipun masih belum benar seluruhnya dan anak usia sekolah mengetahui tentang menggosok gigi yang benar.

Hasil pendidikan kesehatan yang didapatkan bahwa pengetahuan peserta rata-rata sebelum dilakukan pendidian kesehatan 55,3\% kurang pengetahuan tentang menggosok gigi dan setelah dilakukan penyuluhan selama 45 menit terhadap 38 peserta didapatkan hasil posttest $78,9 \%$ yang artinya terdapat 
peningkatan sebelum dan sesudah sebesar $26,3 \%$.

\section{Saran}

Hasil pendidikan kesehatan ini diharapkan dapat memberikan tambahan formasi bagi pihak puskesmas tentang pengetahuan, dan praktik menggosok gigi pada anak usia sekolah, sehingga petugas puskesmas diharapkan dapat memebrikan penyuluhan kesehatan secara rutin pada siswa sekolah dasar.

Rencana tindak lanjut dari permasalahan kebersihan gigi dan mulut akan berkoordinasi dengan piham puskesmas Putri Ayu dalam Program usaha kesehatan gigi sekolah (UKKGS) untuk mengadakan penyuluhan tentang karies gigi disekolah-sekolah yang dilaksanakan setiap 6 bulan sekali.

\section{UCAPAN TERIMA KASIH}

Terimakasih yang tak terhingga kepada Sekolah Tinggi Ilmu Kesehatan Baiturrahim Jambi yang memberikan kemudahan dalam pelaksanaan penelitian ini. Selain itu penulis juga mengucapkan terimaksih kepada ketua RT. 10 Kelurahan Murni, Kota Jambi karena telah dengan senang hati menerima dan membantu proses pengabdian masyarakat ini sehingga kegiatan ini bisa terlaksana dan berjalan lancar.

\section{DAFTAR PUSTAKA}

Arisman.2009. Gizi dalam DAUR KEHIDUPAN. Jakarta : ECG.

Gayatri.2017. Hubungan Tingkat Pengetahuan Dengan Perilaku Pemeliharaan Kesehatan Gigi Anak SDN Kauman 2 Malang. Malang . Jurnal of health education.

Hartono \& Enny,M.R.2010. Diagnosis kelainan Dalam Mulut : Petunjuk Bagi Klinis.Jakarta : EGC.

Irma \& Intan. 2013. Penyakit Gigi, Mulut dan THT. Yogyakarta : Nuha Medika
Kemenkes RI.2018. Profil Kesehatan Indonesia tahun 2017. Jakarta: Kemenkes RI

Machfoedz dan Zein. 2018. Menjaga kesehatan gigi dan mulut anak anak dan ibu hamil. Yogyakarta : Fitramaya

Prasko. 2018. Hpenyuluhan Metode Audio Visual Dan Demonstrasi Terhadap Pengetahuan Menyikat Gigi Pada Anak Sekolah Dasar". Jakarta : Jurnal Kesehatan gigi.

Pratiwi. 2017. Gigi sehat merawat gigi sehari - hari. Jakarta : Kompas

Riskesdas 2018. Data Tentang Kesehatan Gigi dan Mulut pada Anak

Sri.,Handayani. $2017 . \quad$ Pengaruh Penyuluhan Mengenai Menyikat Gigi Yang Benar Terhadap Peningkatan Pengetahuan. Padang : Jurnal Kesehatan Medika Saintika.

Srigupta.2009. Panduan Singkat Perawatan Gigi \& Mulut. Jakarta : Prestasi Pustaka.

Susilowati \& Kuspriyanto.2016. Gizi Dalam DAUR KEHIDUPAN. Bandung : PT Refika Aditama.

Sumawinata,Narlan.2008. Prinsip dan Praktik Ilmu Endodonsia,Ed.3.Jakarta : EGC

Fatmawati, T. Y. (2018). Pengaruh Pendidikan Kesehatan Terhadap Pengetahuan Tentang Personal Hygiene Pada Anak Usia Sekolah Di Sdn 206/Iv Kota Jambi. Jurnal Akademika Baiturrahim Jambi, 7(1), 10.

https://doi.org/10.36565/jab.v7i1.56

Wong,D,dkk.2009. Buku Ajar Keperawatan Pediatrik. Volume 1. Penerbit Buku Kedokteran EGC : Jakarta 